\title{
Aspects of the ecology of the mesopelagic fish Gonostoma elongatum (Gonostomatidae, Stomiiformes) in the eastern Gulf of Mexico
}

\author{
Thomas M. Lancraft, Thomas L. Hopkins, Joseph J. Torres \\ Department of Marine Science, University of South Florida, 140 7th Avenue South, St Petersburg, Florida 33701, USA
}

\begin{abstract}
Gonostoma elongatum is an important mesopelagic fish found throughout the world at subtropical-tropical latitudes. This study examined its distribution, abundance and life history in the eastern Gulf of Mexico. The species was a strong diel migrator, found from 25 to $325 \mathrm{~m}$ at night and from 425 to $725 \mathrm{~m}$ during the day with small fish occurring shallower than large fish. Numerical abundance and biomass were high, rivalling the dominant species of myctophids in the Gulf of Mexico. There were no obvious seasonal fluctuations in population abundance. G. elongatum is a protandric hermaphrodite whose population breeds throughout the year and females probably once a lifetime. Growth rate, based on 'daily' ring counts from otoliths, was linear $\left(0.34 \mathrm{~mm} \mathrm{~d}^{-1}\right)$ and the largest fish (225 $\mathrm{mm}$ Standard Length) was estimated to live less than 2 yr G. elongatum feeds primarily on crustaceans, with copepods and ostracods dominating in early juvenile stages $(<50 \mathrm{~mm} \mathrm{SL})$ and euphausiids in the larger sizes. Diet composition shows little apparent seasonal variation. Size selectivity in feeding occurs, with G. elongatum preferentially ingesting medium to large zooplankton, a trend which becomes stronger with age. Taxonomic selectivity occurs as well in that this species preferentially feeds on conchoecid ostracods and copepods Pleuromamma spp. There is an obvious selection against non-crustacean prey. A cyclic feeding pattern was observed with most active feeding occurring in the 25 to $250 \mathrm{~m}$ zone at night. While $G$. elongatum has relatively little predation impact on one of its principal foods (Pleuromamma spp.) over the entire zone of occurrence of this prey genus, predation is substantial on large Pleuromamma (>3 mm) in certain depth zones $(150$ to $200 \mathrm{~m}$ ) at night.
\end{abstract}

\section{INTRODUCTION}

Gonostoma elongatum, a member of the mesopelagic fish family Gonostomatidae, is found throughout most of the world ocean (Mukhacheva 1972) with its maximum abundance in the circumglobal belt of tropicalsubtropical waters (Badcock 1984). It has been placed among the top 3 numerically dominant stomiiform species, Cyclothone excluded, in the northern and equatorial Atlantic (Backus et al. 1970, Backus \& Craddock 1982), the Gulf of Mexico (Hopkins \& Lancraft 1984) and the central Pacific (Clarke 1974). It is a highly fecund protandric hermaphrodite (Fisher 1983). We report on its vertical distribution and abundance (diel and seasonally), and aspects of its growth and reproduction.

The present paper also describes the trophic ecology of Gonostoma elongatum including information on diet composition, changes in diet with ontogeny, prey selec- tivity and feeding chronology. Our data are compared with the findings of others on the nutrition of $G$. elongatum (e.g. Clarke 1978, Gorelova 1981) and estimates of the predation impact of this species on its zooplankton food resources in the eastern Gulf are discussed.

\section{METHODS}

Gonostoma elongatum was collected during 11 cruises between June 1975 and March 1987 within a 20 mile radius of $27^{\circ} \mathrm{N}, 86^{\circ} \mathrm{W}$ in the eastern Gulf of Mexico. The first 3 cruises, on the RV 'Columbus Iselin', were made during the summers of 3 successive years (June 1975, June 1976, September 1977). The 8 remaining cruises were on the RV 'Suncoaster' from September 1984 to March 1987 (Table 1).

Three different opening-closing modified Tuckertype trawls (Hopkins \& Baird 1975) were used: one 
Table 1. Summary of sampling effort on 11 cruises conducted during the study

\begin{tabular}{|c|c|c|c|c|}
\hline \multicolumn{5}{|c|}{ 1975-1977 díscrete depth tows } \\
\hline \multirow[t]{2}{*}{ Depth $(m)$} & \multicolumn{2}{|c|}{ Day } & \multicolumn{2}{|c|}{ Night } \\
\hline & $\begin{array}{l}\text { Vol. filt. } \\
\left(10^{4} \mathrm{~m}^{3}\right)\end{array}$ & $\begin{array}{l}\text { No. } \\
\text { tows. }\end{array}$ & $\begin{array}{l}\text { Vol. filt. } \\
\left(10^{4} \mathrm{~m}^{3}\right)\end{array}$ & $\begin{array}{l}\text { No. } \\
\text { tows }\end{array}$ \\
\hline $50-100$ & 0.8 & 1 & 5.4 & 3 \\
\hline $100-150$ & 9.1 & 5 & 16.0 & 9 \\
\hline $150-200$ & 3.2 & 2 & 1.4 & 1 \\
\hline $200-250$ & 1.6 & 1 & 4.3 & 3 \\
\hline $275-325$ & 5.5 & 3 & 9.4 & 5 \\
\hline $325-375$ & 1.0 & 1 & 1.4 & 1 \\
\hline $375-425$ & 3.0 & 2 & 3.7 & 3 \\
\hline $425-475$ & 5.9 & 4 & 4.3 & 3 \\
\hline $475-525$ & 4.2 & 4 & 4.1 & 3 \\
\hline $525-575$ & 5.2 & 4 & 6.2 & 4 \\
\hline $575-625$ & 9.1 & 4 & 5.8 & 2 \\
\hline $625-675$ & 1.0 & 1 & - & - \\
\hline $675-725$ & 4.6 & 2 & 2.4 & 1 \\
\hline $775-825$ & 3.6 & 2 & 3.8 & 2 \\
\hline $900-1000$ & 6.2 & 3 & 6.2 & 3 \\
\hline $1000-1100$ & 1.8 & 1 & 6.6 & 3 \\
\hline \multirow[t]{2}{*}{$1100-1300$} & 1.9 & 1 & 1.8 & 1 \\
\hline & 67.7 & 41 & 82.8 & 47 \\
\hline \multicolumn{5}{|c|}{ 1984-1987 series (night only) } \\
\hline \multirow[t]{2}{*}{ Month } & \multicolumn{2}{|c|}{$\begin{array}{l}\text { Discrete depth tows } \\
(0-25 \mathrm{~m}, 25-50 \mathrm{~m} \text { zones })\end{array}$} & \multicolumn{2}{|c|}{$\begin{array}{l}\text { Oblique depth tows } \\
(0-200 \mathrm{~m} \pm 25 \mathrm{~m})\end{array}$} \\
\hline & $\begin{array}{l}\text { Vol. filt. } \\
\left(10^{4} \mathrm{~m}^{3}\right)\end{array}$ & $\begin{array}{l}\text { No. } \\
\text { tows }\end{array}$ & $\begin{array}{l}\text { Vol filt. } \\
\left(10^{4} \mathrm{~m}^{3}\right)\end{array}$ & $\begin{array}{l}\text { No. } \\
\text { tows }\end{array}$ \\
\hline Sep 1984 & 2.9 & 1 & 22.2 & 14 \\
\hline Mar 1985 & 8.9 & 3 & 51.4 & 30 \\
\hline Jul 1985 & 1.8 & 2 & 37.3 & 23 \\
\hline Nov 1985 & 2.6 & 3 & 42.8 & 25 \\
\hline Jan 1986 & 1.3 & 1 & 43.7 & 24 \\
\hline May 1986 & 2.3 & 2 & 32.4 & 22 \\
\hline $\operatorname{Jan} 1987$ & - & - & 36.6 & 24 \\
\hline \multirow[t]{2}{*}{ Mar 1987} & 1.4 & 1 & 36.8 & 23 \\
\hline & 21.2 & 13 & 303.2 & 185 \\
\hline
\end{tabular}

with a $5.3 \mathrm{~m}^{2}$ mouth opening (effective fishing area) with a main net constructed of $4 \mathrm{~mm}$ square mesh, one trawl with a $2.65 \mathrm{~m}^{2}$ mouth area using $4 \mathrm{~mm}$ mesh, and one with a $2.65 \mathrm{~m}^{2}$ mouth area trawl and $1.6 \mathrm{~mm}$ square mesh size. The latter trawl was used only on the 'Suncoaster' cruises, in conjunction with the other 2 trawls. All main nets tapered down to a plankton net (1 mm square mesh) and terminated in a $1 \mathrm{~mm}$ square mesh cod end net and bucket. The trawls were towed at an average speed of 2 knots. Each trawl was equipped with a collapsible $66 \times 66 \mathrm{~cm}, 163 \mu \mathrm{m}$ mesh plankton net nested within the main net (Hopkins \& Baird 1975). The trawls were opened and closed with messenger or clock actuated release devices (Davies \& Barham 1969). The volume of water filtered was recorded by dial-type flowmeters only when the net was fishing (Hopkins \& Baird 1975). Tow depth was monitored through wire angle measurements or an electronic depth transducer system and documented with a time-depth recorder. A fish catcher - a shallowconed retaining net of $4 \mathrm{~mm}$ mesh located well ahead of the cod end net - was used to prevent fish from mixing with and feeding on the plankton in the trawl cod end. During the 'Suncoaster' cruises expendable bathythermograph (XBT) casts down to $900 \mathrm{~m}$ were conducted daily or more frequently within the study area.

The smaller $(1.6 \mathrm{~mm})$ mesh was used to estimate the effect of mesh size on catch abundances and insure capture of the smallest post-larval fish $(23 \mathrm{~mm}$ standard length, SL: Loeb 1979). Assuming a 5:1 length:height ratio (Grey 1964) minimum cross-sectional diameter was greater than $4 \mathrm{~mm}$ for a $23 \mathrm{~mm}$ SL fish.

All fish were either preserved in buffered $10 \%$ formaldehyde solution or blotted of excess water and frozen immediately after capture. Preserved specimens were subsequently transferred to $50 \%$ isopropanol. Some specimens were measured before freezing, but all fish, frozen or preserved, were measured to the nearest millimeter standard length (mm SL) in the laboratory. Shrinkage due to freezing was negligible as lengths did not differ significantly (paired $t$-test, $t>0.5$, $n=62$ ) in those fish measured before and after freezing. Length-weight curves were generated using the least squares method for the frozen specimens. The length-wet weight relation based on 355 fish ( \pm $0.001 \mathrm{~g})$ is:

$$
\mathrm{W}=4.0 \times 10^{-6} \mathrm{~L}^{2.984} \quad\left(r^{2}=0.99\right)
$$

where $\mathrm{W}=\mathrm{g}$ wet weight $(\mathrm{WW}) ; \mathrm{L}=\mathrm{mm} \mathrm{SL}$. The length-dry weight expression, determined by drying 27 fish to constant weight $( \pm 0.001 \mathrm{~g})$ at $60^{\circ} \mathrm{C}$ is:

$$
\mathrm{W}=2.3 \times 10^{-6} \mathrm{~L}^{2.628} \quad\left(r^{2}=0.99\right)
$$

where $W=g$ dry weight $(D W)$.

The diel vertical distribution of Gonostoma elongatum was primarily determined from discrete horizontal tows between 50 and $1300 \mathrm{~m}$ using $4 \mathrm{~mm}$ mesh nets on the 'Columbus Iselin' cruises. Supplementary discrete tows from the 0 to $25 \mathrm{~m}$ and 25 to $50 \mathrm{~m}$ zones were made from the 'Suncoaster' cruises, making a total of 19 depth horizons fished. A summary of the number of tows and volume of water filtered from each discrete depth horizon is given in Table 1. The tows in the 0 to $25 \mathrm{~m}$ zone were conducted during all seasonal sampling periods. To make a clear separation between day and night, no fishing was done within $1 \frac{1}{2} \mathrm{~h}$ of dawn or dusk. Abundance values (numbers per $10^{4} \mathrm{~m}^{3}$ ) were determined by dividing the total number of fish collected by the volume filtered for each depth horizon. To determine biomass ( $\mathrm{mg}$ DW per $10^{4} \mathrm{~m}^{3}$ ), the dry weight 
of each fish was calculated using the length-dry weight expression, summed with the dry weight of all fish collected in that horizon, and then divided by the volume of water sampled.

Numerical abundance and biomass were integrated down to $200 \mathrm{~m}$ and $1000 \mathrm{~m}$ for both day and night. This was done by multiplying the appropriate density or biomass concentration (adjusted to a $\mathrm{m}^{3}$ basis) for each horizon by the depth range, in meters, of that horizon and then summing the products vertically.

Seasonal aspects of biomass, numerical abundance, and percentage composition of juveniles and mature adults were analysed by using the oblique 0 to $200 \mathrm{~m}$ ( $\pm 25 \mathrm{~m}$ ) night tows taken during the 8 'Suncoaster' cruises (Table 1). These tows captured the complete size range of Gonostoma elongatum (see 'Results') but since the entire depth range was not sampled the biomass and abundance values were considered for seasonal comparisons and not for absolute estimates of total population abundance. Seasonal biomass values ( $\mathrm{mg} \mathrm{DW} \mathrm{m}^{-2}$ ) for $G$. elongatum were calculated by summing the dry weight of all fish from all of each cruise's 0 to $200 \mathrm{~m}$ tows, dividing by the total water filtered, and then multiplying by the depth of the sampled water column $(200 \mathrm{~m})$. Seasonal numerical abundances (number $\mathrm{m}^{-2}$ ) were determined by calculating the quotient of total number of fish per water volume filtered for all 0 to $200 \mathrm{~m}$ tows in each cruise, and then multiplying by $200 \mathrm{~m}$. Except for specimens from the July 1985 cruise, gonads were removed from all individuals $110 \mathrm{~mm}$ SL or larger and assigned a reproductive maturity state according to the criteria established by Fisher (1983). This size range contains gonads from most of the ripe males, all ripe females, and some hermaphrodites (Fisher 1983).

Growth rate was estimated by counting the daily rings' in sagittae (otoliths) which were removed from frozen or fresh fish after they had been measured and sexed. The otoliths were then cleaned, stored dry, and later mounted whole on microscope slides with a clear synthetic mounting medium. The number of increments were counted at high magnifications (400 to $1000 \times$ ) under immersion oil using a microscope-video camera system. The video system magnified and enhanced the contrast of the increment image. To eliminate bias, each otolith was assigned an arbitrary number, without listing fish length or sex. The number of increments were counted twice by one observer (T.M.L.) on separate days and if the 2 counts varied by greater than $5 \%$ from a mean of the 2 then a third reading was performed. If the third reading was not within the percentage range then that otolith was discarded $(n=3)$. While the periodicity of primary zones is generally thought to be daily in nature (see 'Discussion') laboratory verification was impossible because
Gonostoma elongatum rarely survives more than a day after capture.

Kolmogorov-Smirnov 2-sample tests between mesh sizes and net mouth sizes for abundance of fish in $15 \mathrm{~mm}$ size class intervals ( 21 to $185 \mathrm{~mm} \mathrm{SL}, 11$ classes) for all 8 seasonal collections were performed to evaluate the catching abilities of the different net sizes and meshes. An ANOVA was used to test if median seasonal abundances varied relative to net mouth size.

Fishes used in diet analysis were measured (mm SL) before their digestive tracts were removed. The digestive tract was opened longitudinally with iris scissors and the contents removed to small watch glasses or microscope slides. All material was microscopically examined in water and separate records were kept for stomach and intestinal contents. The Gonostoma elongatum size classes considered for diet analysis were $20-29, \quad 30-50, \quad 51-79, \quad 80-100, \quad 110-130$ and $131-150 \mathrm{~mm}$ SL. The numbers of fish examined for each size class were, respectively, 28, 114, 29, 121, 208 and 15.

Identification of food items was made to species, if possible. When whole prey animals were encountered, measurements were made of total length to the nearest $0.1 \mathrm{~mm}$. The dimensions measured for each type of prey are described in Hopkins (1982). In cases of fragmented prey, key morphological features were measured which could be related to total size through regressions of these fragment dimensions versus total animal size (Hopkins 1987). The prey most commonly fragmented were ostracods, copepods and euphausiids. Linear regressions on total length were obtained for the most commonly occurring body parts of prey. The basal segment (length) of the second antennae and mandibles (width) were measured in ostracods. Mandibles (width) were used in copepods and, for Pleuromamma, the metasomal spot (diameter). Eyes (diameter) were measured in euphausiids. Analysis of the diet information indicated that 15 to 20 fish with food in their guts were enough for estimating within $5 \%$ the relative abundance of the dominant food taxa in a fish sample.

Feeding chronology was addressed by dividing the diel period into 7 time (local) intervals, 19:00 to 21:00. $21: 00$ to $23: 00,23: 00$ to $1: 00,1: 00$ to $3: 00,3: 00$ to $5: 00$, 7:00 to $13: 00$, and $13: 00$ to $18: 00 \mathrm{~h}$, then assigning the dietary data to the appropriate time of fish capture. Three size classes of Gonostoma elongatum were considered $(30-50,80-100$ and $110-130 \mathrm{~mm} \mathrm{SL})$, and the information used was the total number of prey in the digestive tract.

Information on the principal zooplankton prey of Gonostoma elongatum comes from 2 sets of samples. One set, reported in Hopkins (1982), was taken during the RV 'Columbus Iselin' cruises (Table 1). These col- 
lections provided averaged data for summer on vertical distribution of major food taxa in the day and night zones of occurrence of $G$. elongatum. Also, the data used in the discussion on the vertical distribution and abundance of various species and size classes of the copepod genus Pleuromamma comes from a master's thesis (Bennett 1986) based on these collections. The second set, providing seasonal data, comes from the RV 'Suncoaster' cruises (Table 1). Six samples were analyzed from each cruise with these being taken in the period 21:30 to 4:00 h, 3 from pre-midnight and 3 from post-midnight. Four aliquots were examined from each sample using the procedures detailed in Hopkins (1982) and the results of the aliquot analyses ( $n=24)$ for each cruise were averaged.

\section{RESULTS}

\section{XBT data}

Winter and summer temperature profiles represent the maximum seasonal variation during all cruises from our sampling site (Fig. 1). The mixed layer ranged from 20 to $40 \mathrm{~m}$ but generally occurred at less than $25 \mathrm{~m}$ throughout the year.

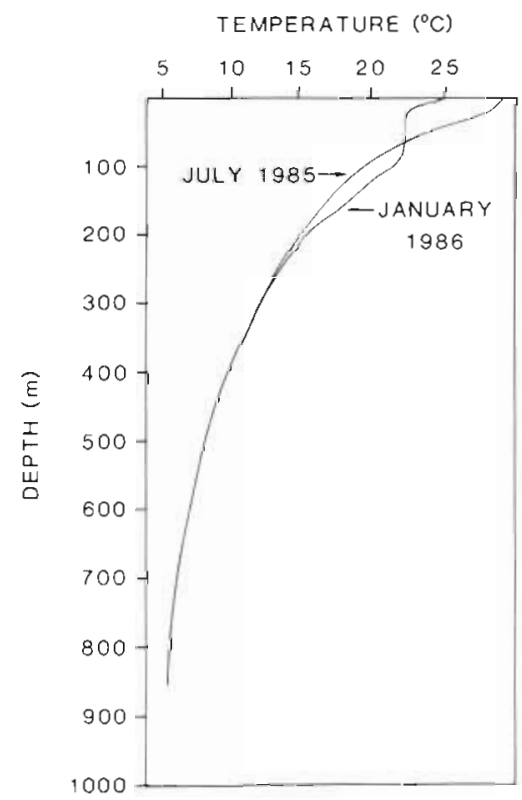

Fig. 1. Winter and summer temperature profiles from the eastern Gulf of Mexico $\left(27^{\circ} \mathrm{N}, 86^{\circ} \mathrm{W}\right)$

\section{Net comparisons}

Comparison of abundances of fish in all size categories between different mesh sizes (1.6 vs $4 \mathrm{~mm}$ square) for all 8 seasonal collections showed no mesh- related, statistically different catches (KolmogorovSmirnov 2-sample tests, all 8 cruises, $p>0.05$ ). Using 0 to $200 \mathrm{~m}$ tows $(n=185$ ) a comparison (ANOVA, $p>$ $0.3)$ of the median seasonal abundances between net mouth sizes $\left(5.3\right.$ vs $\left.2.65 \mathrm{~m}^{2}\right)$ showed no significant differences in catch abundances related to net mouth size for any sampling period. Additionally, there were no differences in abundances of all size categories between net mouth sizes for any cruise (KolmogorovSmirnov tests, $p>0.05$ ). This data indicated that our $4 \mathrm{~m}$ mesh nets were adequate for sampling the entire post-metamorphic population of Gonostoma elongatum. Therefore, all tows were grouped to determine seasonal numerical abundances and biomasses.

\section{Diel vertical distribution and abundance}

A total of 275 specimens ranging from 21 to $162 \mathrm{~mm}$ SL were collected in the horizontal discrete tow series (Table 1). Gonostoma elongatum was a strong diel migrator with the entire population moving from nighttime depths of 25 to $325 \mathrm{~m}$ to daytime depths of 425 to $725 \mathrm{~m}$ (Fig. 2). Night-time and daytime abundance peaks were at 200 and $600 \mathrm{~m}$, respectively. Despite the intensive night-time trawling program, no fish were

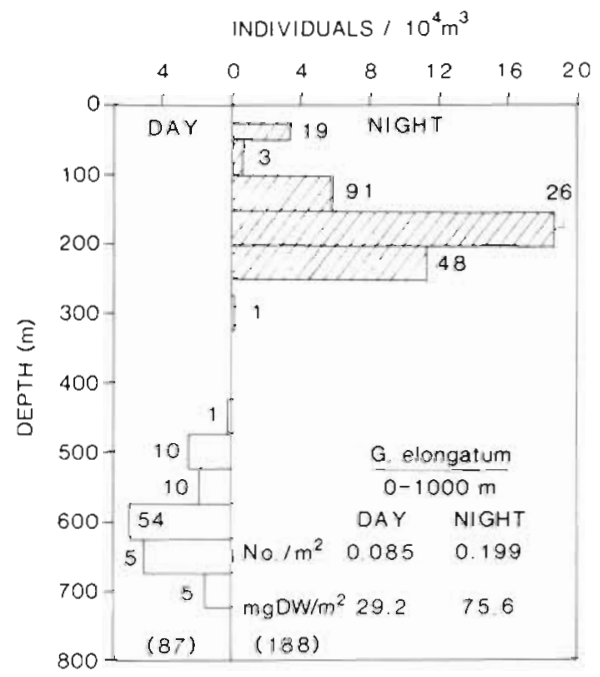

Fig. 2. Gonostoma elongatum. Diel vertical distribution Numbers beside bars are sample sizes; totals are in parentheses. Diel integrated 0 to $1000 \mathrm{~m}$ abundance and biomass values also presented

captured from the upper $25 \mathrm{~m}$ (mixed layer) from any cruise. Larger fish lived and migrated in deeper depth horizons than did smaller fish (Fig. 3).

In the horizontal tow series twice as many specimens (188 vs 87 ) and higher standardized abundances were collected at night than during the day. Because day- 


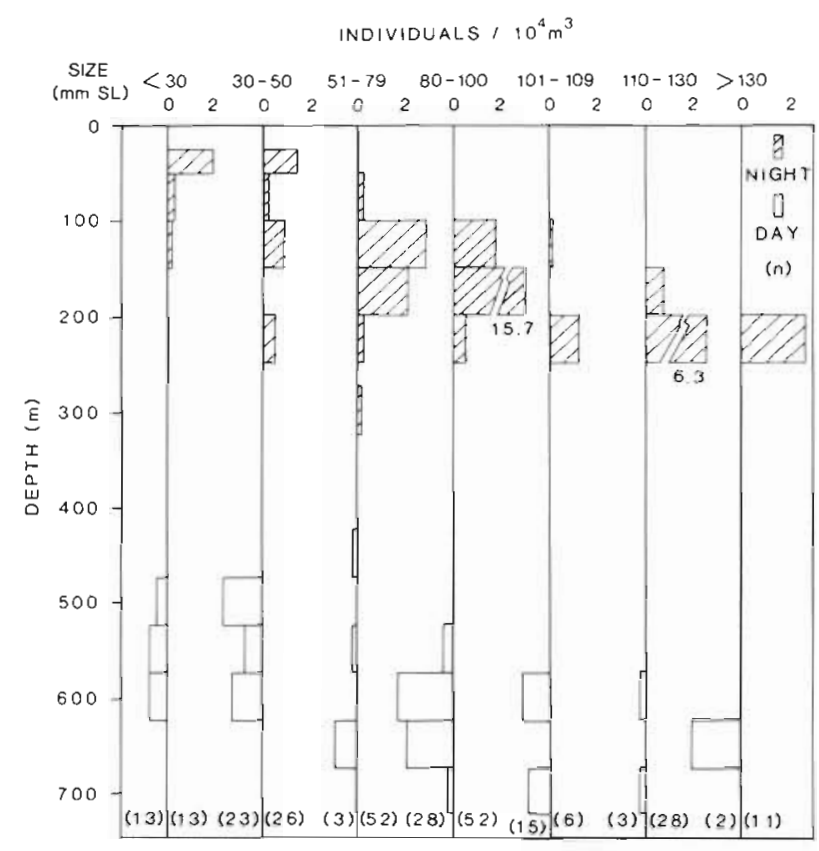

Fig. 3. Gonostoma elongatum. Diel depth distribution for each size class ( $\mathrm{mm} \mathrm{SL}$ )

time net avoidance seemed likely, night-time values were taken as the most accurate estimates of abun. dance and biomass. Night-time integrated 0 to $1000 \mathrm{~m}$ values for abundance and biomass were $0.199 \mathrm{fish} \mathrm{m}^{-2}$ and $75.6 \mathrm{mg} \mathrm{DW} \mathrm{m}^{-2}$, respectively (Fig. 2).

\section{Seasonal abundance and reproduction}

A total of 1698 fish (22 to $225 \mathrm{~mm} \mathrm{SL}$ ) were collected in 185 night-time oblique tows $(0$ to $200 \mathrm{~m}$ ) during the 8 seasonal cruises. Mean abundance for all seasons combined was 0.109 fish $\mathrm{m}^{-2}$ in the upper $200 \mathrm{~m}$ (Fig. 4A) and mean biomass was $28.7 \mathrm{mg} \mathrm{DW} \mathrm{m}^{-2}$ (Fig. 4B).

No major seasonal reproductive patterns were present as post-larval juveniles $(21-50 \mathrm{~mm} \mathrm{SL})$ were abundant almost all year around (Fig. 4C) and reproductively mature individuals of both sexes were found during all collection periods (Fig. 4D). Post-larval juveniles averaged nearly $40 \%$ of the sampled population in most seasons. A total of $179(14.4 \%)$ ripe gonads were found in the 1247 fish collected (July 1985 excluded; sample destroyed). Ripe males accounted for $9.9 \%$ of all fish and ripe females accounted for $4.5 \%$. The median sizes of ripe males ( $n$ $=123)$ and females $(n=56)$ were $115 \mathrm{~mm} \mathrm{SL}$ (110-134 mm SL) and $161 \mathrm{~mm}$ SL (135-225 mm SL), respectively. All fish greater than $163 \mathrm{~mm}$ SL were ripe females. Only 6 females (about $10 \%$ of the ripe females) were greater than $180 \mathrm{~mm}$, the mid-range

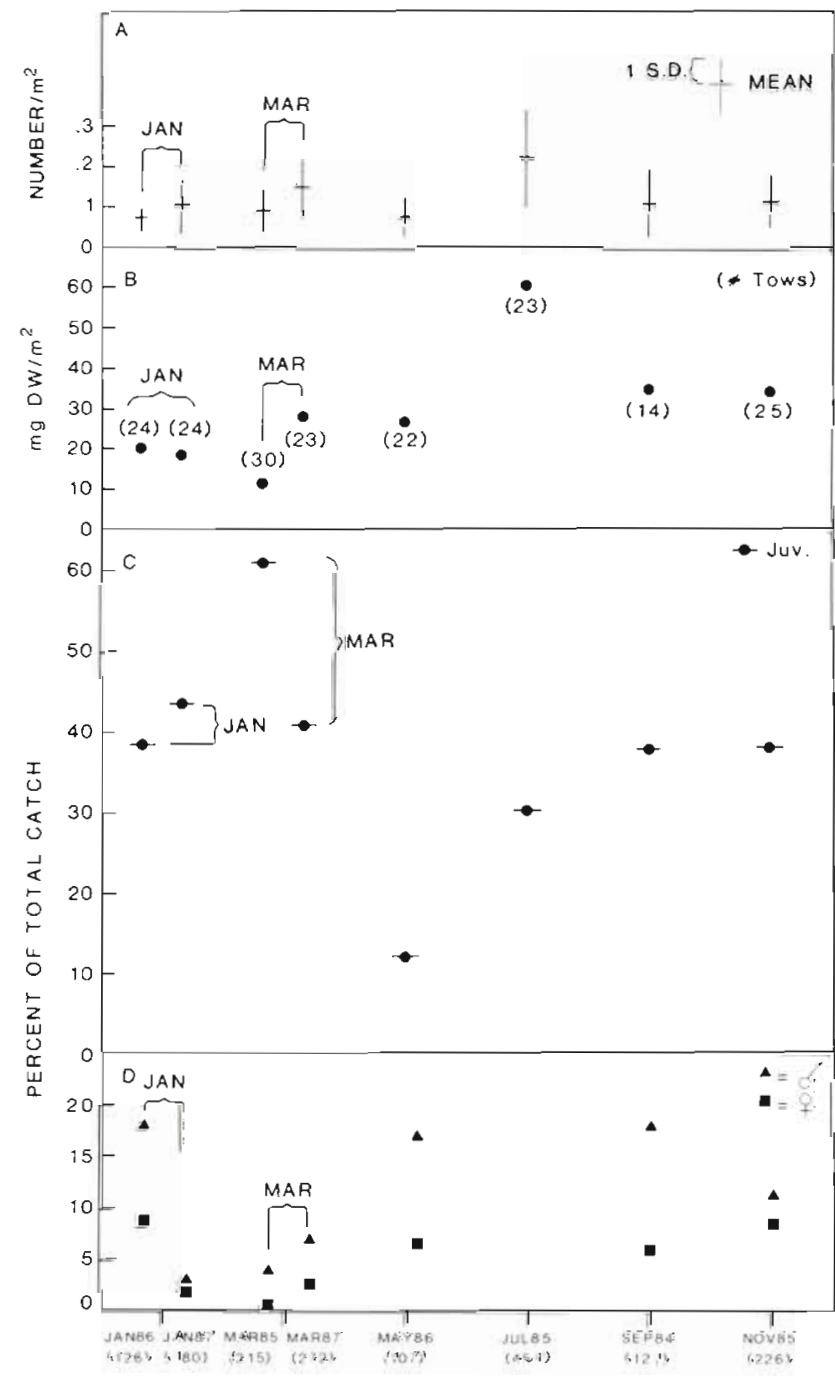

Fig. 4. Gonostoma elongatum. (A) Seasonal population abundance, and (B) biomass; (C) seasonal juvenile (21-50 mm SL) abundance, and (D) sexually mature adult abundance. Data taken from 1984 to 1987 oblique 0 to $200 \mathrm{~m}$ tow series

point. The occurrence of ripe males may have been underestimated since males smaller than $110 \mathrm{~mm} \mathrm{SL}$ were not examined but this did not affect the observed absence of seasonality of reproduction. Gravid females rarely $(n=3)$ carried more than one size class of eggs and no spent ovaries were observed.

\section{Growth}

The otoliths of Gonostoma elongatum were small (<3 mm in diameter), only slightly concave, and nearly transparent so whole otoliths could be mounted and examined without further treatment. The rings were distinct though narrow (1 to $3 \mu \mathrm{m}$ ) allowing for generally good readability. The numbers of increments 


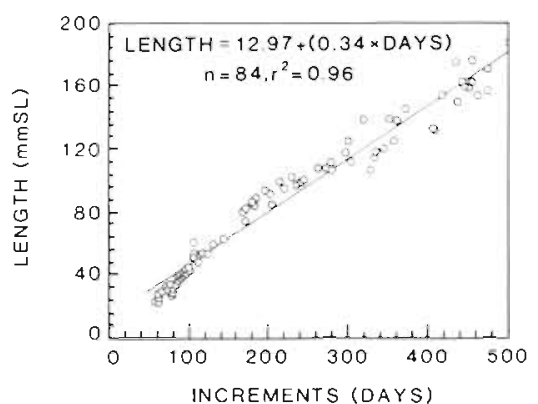

Fig. 5. Gonostoma elongatum. Growth rate (length, $\mathrm{mm} \mathrm{SL}$ ) in the eastern Gulf of Mexico

counted in 84 otoliths taken from fish ranging from 23 to $187 \mathrm{~mm} \mathrm{SL}$ were regressed against fish length (Fig. 5) using a variety of models with the best fit resulting in the linear growth rate expression of:

$$
\text { Length }=12.97+(0.34 \times \text { Increments }) \quad\left(r^{2}=0.96\right)
$$

where length is in $\mathrm{mm} \mathrm{SL}$ and increments are assumed to be days. The growth rate averaged over the entire size range was $0.34 \mathrm{~mm} \mathrm{~d}^{-1}$. Using this growth rate, onset of sexual maturity for males $(110 \mathrm{~mm} \mathrm{SL})$ and females (135 $\mathrm{mm} \mathrm{SL}$ ) began at 9 and $12 \mathrm{mo}$, respectively. The median sized ripe female lived to $15 \mathrm{mo}$; after this period female abundance dropped rapidly so only $10 \%$ of the females survived over $16 \mathrm{mo}(180 \mathrm{~mm}$ $\mathrm{SL})$. The maximum calculated age for females at the largest observed size ( $225 \mathrm{~mm} \mathrm{SL}$ ) was $21 \mathrm{mo}$.

Increments near the center of the otolith were the widest and most distinct but they narrowed abruptly at a point 51 to 67 increments (mean $=57.3$ ) from the center. The total number of increments counted in otoliths from four $23 \mathrm{~mm}$ SL recently metamorphosed fish ranged from 56 to 63 and averaged 60 increments, suggesting a 2 mo pre-metamorphic period.

\section{Feeding}

The diets of 3 size classes of Gonostoma elongatum from July 1985 collections are listed in Table 2. The diet of $G$. elongatum was composed overwhelmingly of Crustacea, with this group constituting 92 to $98 \%$ of the food items identified. Food was taxonomically diverse and copepods accounted for most of the diversity and numbers of prey eaten. Pleuromamma was the obviously predominant genus. Two other important prey groups were conchoecid ostracods and euphausiids, particularly representatives of the genera Nematoscelis and Stylocheiron.

Size-related changes in diet were apparent. The data in Fig. 6 show a relative decrease in biomass contribution of copepods and ostracods and a corresponding

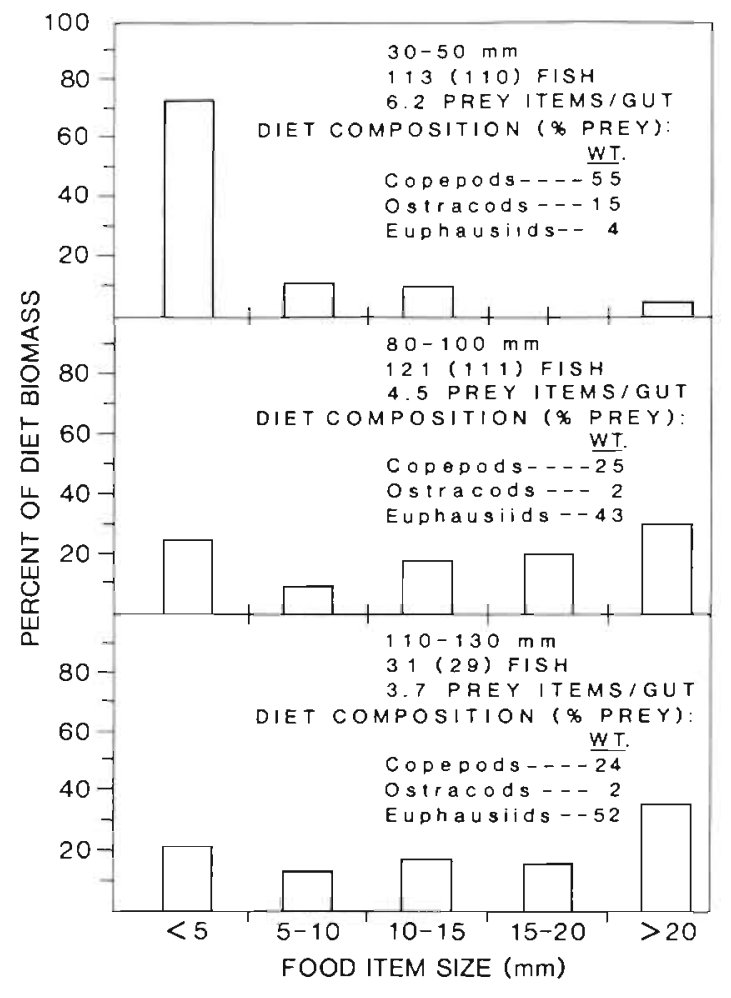

Fig. 6. Gonostoma elongatum. Biomass composition of diets of 3 size classes. Numbers in parentheses are numbers of fish examined which contained identifiable food

increase in the importance of euphausiids with increasing size of Gonostoma elongatum. Thus, larger prey become increasingly more important in the nutrition of this species with fish growth. This is demonstrated in Fig. 7, a size-frequency plot of prey eaten by 5 size classes of $G$. elongatum.

While Gonostoma elongatum fed on a broad spectrum of prey, there is evidence for both size and tax-

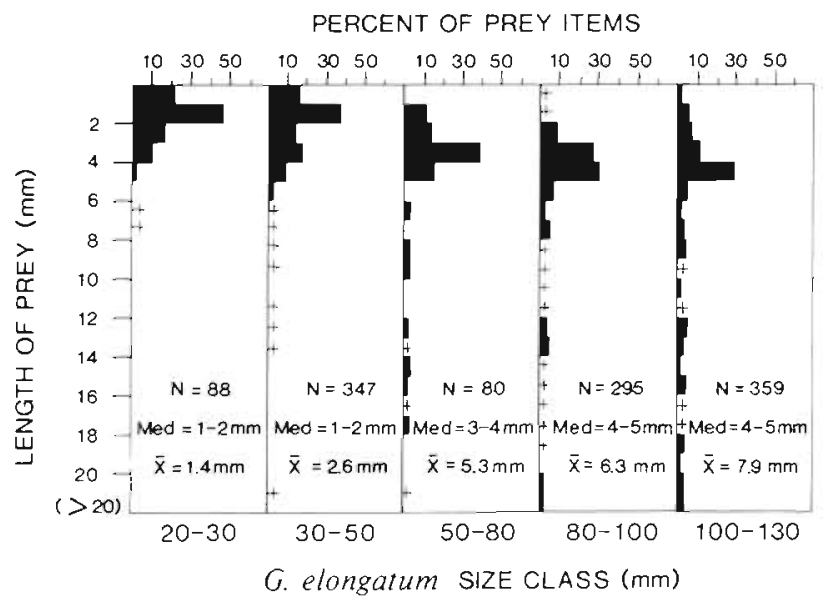

Fig. 7. Gonostoma elongatum. Size-frequency distribution of food items in 5 size classes. $+\cdot<1 \%$ 
Table 2. Gonostoma elongatum. Diet composition of 3 size classes. $N$ : number of fishes examined

\begin{tabular}{|c|c|c|c|}
\hline Prey taxa & $\begin{array}{l}30-50 \mathrm{~mm} \\
(N=114)\end{array}$ & $\begin{array}{c}80-100 \mathrm{~mm} \\
(N=121)\end{array}$ & $\begin{array}{c}110-130 \mathrm{~mm} \\
(N=31)\end{array}$ \\
\hline \multicolumn{4}{|l|}{ COPEPODA } \\
\hline Aegisthus spp & 2 & - & - \\
\hline Candacia bipinnata & 5 & - & - \\
\hline Candacia curta & 3 & - & - \\
\hline Candacia longimana & 5 & 7 & - \\
\hline Candacia pachydactyla & 2 & - & - \\
\hline Candacia varicans & 5 & 3 & - \\
\hline Candacia spp. & 4 & 1 & 1 \\
\hline Chirundina streetsi & - & 11 & 4 \\
\hline Corycaeus clausi & - & - & 1 \\
\hline Corycaeus lautus & 3 & - & - \\
\hline Corycaeus speciosus & 1 & - & - \\
\hline Corycaeus spp. & - & 4 & - \\
\hline Euaetideus sp. & - & 1 & - \\
\hline Eucalanus sewelli & 3 & 1 & - \\
\hline Eucalanus sp. & 1 & - & - \\
\hline Euchaeta marina & 1 & 1 & - \\
\hline Euchaeta media & 4 & 7 & 1 \\
\hline Euchaeta spinosa & - & 1 & - \\
\hline Euchaeta spp. & 6 & 5 & - \\
\hline Euchirella amoena & - & 1 & - \\
\hline Euchirella messinensis & - & 1 & - \\
\hline Euchirella pulchra & 1 & 1 & - \\
\hline Euchirella splendens & 1 & - & - \\
\hline Gaetanus spp. & 2 & - & 1 \\
\hline Heterorhabdus spp. & 1 & 2 & - \\
\hline Heterostylites sp. & - & 1 & - \\
\hline Lubbockia spp. & 1 & 1 & - \\
\hline Lucicutia flavicornis & - & 1 & - \\
\hline Nannocalanus minor & 8 & - & - \\
\hline Oncaea spp. & 57 & 26 & 3 \\
\hline Paracandacia simplex & 2 & - & - \\
\hline Phaenna spinifera & 1 & - & - \\
\hline Pleuromamma abdominalis & 101 & 65 & 5 \\
\hline Pleuromamma gracilis & 8 & - & - \\
\hline Pleuromamma piseki & 11 & - & - \\
\hline Pleuromamma xiphias & 58 & 136 & 29 \\
\hline Pleuromamma spp. & 36 & 2 & - \\
\hline Pseudachirella obesa & - & 1 & - \\
\hline Rhincalanus cornutus & 1 & 1 & - \\
\hline Sapphirina metallina & 1 & - & - \\
\hline Sapphirina opalina & 1 & - & - \\
\hline Sapphirina sp. & 1 & - & - \\
\hline Scolecithricella dentata & 2 & - & - \\
\hline Scolecithrix bradyi & 1 & - & - \\
\hline Scolecithrix danae & 10 & - & - \\
\hline Scottocalanus helenae & - & 1 & - \\
\hline Scottocalanus securifrons & 4 & 11 & 2 \\
\hline Scottocalanus thomasi & - & 1 & - \\
\hline Scottocalanus spp. & 3 & 10 & 1 \\
\hline Temora stylifera & 8 & - & - \\
\hline Undeuchaeta major & - & 3 & 1 \\
\hline Undeuchaeta plumosa & 4 & 6 & 1 \\
\hline Unident. copepods & 19 & 6 & 5 \\
\hline \multicolumn{4}{|l|}{ OSTRACODA } \\
\hline Conchoecia atlantica & - & 2 & - \\
\hline Conchoecia curta & 66 & - & - \\
\hline Conchoecia echinata & 4 & 1 & - \\
\hline Conchoecia imbricata & - & 6 & 1 \\
\hline
\end{tabular}


Table 2 (continued)

\begin{tabular}{|c|c|c|c|}
\hline Prey taxa & $\begin{array}{l}30-50 \mathrm{~mm} \\
(N=114)\end{array}$ & $\begin{array}{c}80-100 \mathrm{~mm} \\
(N=121)\end{array}$ & $\begin{array}{c}110-130 \mathrm{~mm} \\
(N=31)\end{array}$ \\
\hline \multicolumn{4}{|l|}{ OSTRACODA } \\
\hline Conchoecia magna & - & 1 & - \\
\hline Conchoecia oblonga & 10 & 6 & - \\
\hline Conchoecia parthenoda & 1 & - & - \\
\hline Conchoecia procera & 5 & 2 & - \\
\hline Conchoecia rotundata & - & 1 & - \\
\hline Conchoecia skogsbergi & 2 & - & - \\
\hline Conchoecia spinifera & 1 & 1 & - \\
\hline Unident. ostracods & 169 & 75 & 14 \\
\hline \multicolumn{4}{|l|}{ AMPHIPODA } \\
\hline Amphithyrus sculpturatus & 2 & - & 1 \\
\hline Amphithyrus sp. & - & 1 & - \\
\hline Anchylomera blossvillii & - & - & 1 \\
\hline Hyperioides sibaginis & - & 2 & - \\
\hline Hyperionyx macrodactyla & - & 1 & 1 \\
\hline Paraphronima sp. & - & 1 & - \\
\hline Phronimopsis spinifera & 2 & - & - \\
\hline Phrosina semilunata & - & 1 & - \\
\hline Primno spp. & 2 & 1 & 2 \\
\hline Unident. Hyperiidae & 16 & 21 & 3 \\
\hline Unident. Platyscelidae & - & 1 & - \\
\hline Unident. Scinidae & 4 & 4 & - \\
\hline Unident. Amphipoda & - & 2 & - \\
\hline \multicolumn{4}{|l|}{ EUPHAUSIACEA } \\
\hline Nematoscelis microps/atlantica & 5 & 32 & 12 \\
\hline Stylocheiron abbreviatum & - & 7 & 2 \\
\hline Stylocheiron affine & 1 & 6 & 1 \\
\hline Stylocheiron carinatum & 2 & - & - \\
\hline Stylocheiron longicorne & - & 2 & - \\
\hline Stylocheiron suhmit & 3 & - & - \\
\hline Stylocheiron spp. & 3 & 7 & 1 \\
\hline Thysanopoda monocantha & - & 2 & 1 \\
\hline Euphausiid larvae & 7 & - & - \\
\hline Unident. euphausiids & 9 & 18 & 5 \\
\hline \multicolumn{4}{|l|}{ DECAPODA } \\
\hline Sergestes sargassi & - & - & 1 \\
\hline Sergestes vigilax & - & 1 & - \\
\hline Sergestes spp. & - & 7 & 2 \\
\hline Decapod larvae & - & 1 & - \\
\hline Unident. decapods & - & 1 & - \\
\hline \multicolumn{4}{|l|}{ SIPHONOPHORA } \\
\hline Eudoxoides mitra & - & - & 1 \\
\hline Calycophoran fragments & 1 & 3 & 2 \\
\hline \multicolumn{4}{|l|}{ POLYCHAETA } \\
\hline Alciopidae & - & 3 & - \\
\hline Unident. polychaetes & 2 & - & - \\
\hline \multicolumn{4}{|l|}{ CHAETOGNATHA } \\
\hline Sagitta spp. & 3 & 1 & 3 \\
\hline \multicolumn{4}{|l|}{ MOLLUSCA } \\
\hline Unident. cephalopods & 1 & 2 & 1 \\
\hline Pteropods & 1 & 1 & - \\
\hline \multicolumn{4}{|l|}{ PISCES } \\
\hline Leptocephalus larvae & 1 & - & - \\
\hline Unident. fishes & - & 10 & 2 \\
\hline
\end{tabular}


Table 3. Gonostoma elongatum. Comparison of percentages of each prey size distribution in diet with that in the plankton at 150 to $200 \mathrm{~m}$ at night (see 'Methods')

\begin{tabular}{|c|c|c|c|}
\hline \multirow[t]{2}{*}{ A. Total zooplankton } & \multicolumn{3}{|c|}{ Prey size class } \\
\hline & $<5 \mathrm{~mm}$ & $5-10 \mathrm{~mm}$ & $>10 \mathrm{~mm}$ \\
\hline \multicolumn{4}{|l|}{ G. elongatum: } \\
\hline $30-50 \mathrm{~mm} \mathrm{SL}$ & 96 & 3 & $<1$ \\
\hline $80-100 \mathrm{~mm} \mathrm{SL}$ & 80 & 9 & 11 \\
\hline $110-130 \mathrm{~mm} \mathrm{SL}$ & 66 & 17 & 17 \\
\hline Zooplankton & 99 & 1 & $<1$ \\
\hline \multirow[t]{2}{*}{ B. Copepods } & \multicolumn{3}{|c|}{ Copepods } \\
\hline & $<2 \mathrm{~mm}$ & $2-4 \mathrm{~mm}$ & $>4 \mathrm{~mm}$ \\
\hline \multicolumn{4}{|l|}{ G. elongatum: } \\
\hline $30-50 \mathrm{~mm} \mathrm{SL}$ & 40 & 46 & 14 \\
\hline $50-100 \mathrm{~mm} \mathrm{SL}$ & 11 & 40 & 49 \\
\hline $110-130 \mathrm{~mm} \mathrm{SL}$ & 9 & 17 & 74 \\
\hline Zooplankton & 96 & 2 & 2 \\
\hline
\end{tabular}

onomic selectivity in food. Table 3 demonstrates that, in general, G. elongatum fed selectively on mid- to large-sized zooplankton with the trend becoming increasingly obvious in larger fish. Selection for midand large-sized copepods is especially apparent.

Taxonomic selectivity is demonstrated in Table 4 which shows that diet composition of $110-130 \mathrm{~mm} \mathrm{SL}$ Gonostoma elongatum was strikingly different from prey composition in the plankton in both the day and night zones of occurrence of this species. Copepods of the genus Pleuromamma and conchoecid ostracods, for example, were proportionately far more abundant in guts than in the plankton. Also, non-crustacean invertebrates (e.g. chaetognaths, tunicates, coelenterates, polychaetes and molluscs) constituted an insignificant fraction of the $G$. elongatum diet whereas in the day/ night zones of occurrence these organisms form 21 to
$65 \%$ of the plankton in the size range of food ingested by $G$. elongatum.

Seasonal variability in diet composition was examined through comparisons of data from 110-130 mm SL Gonostoma elongatum taken in different months during 1984 and 1985 (Table 5). Using the criterion for adequate sample size (i.e. $>20$ fish sample $\left.e^{-1}\right)$, comparisons are probably valid for 5 of the 6 data subsets in that only the March 1985 collection had fewer than 20 fish. While the percentages of the principal diet components varied considerably, no consistent seasonal trend was obvious. Conspicuous variability in specific food types was observed from cruise to cruise, but the combined percentages of the 3 major kinds of prey, copepods, ostracods and euphausiids, were consistently over $85 \%$ of the food items. With the exception of March data, Pleuromamma consistently exceeded $20 \%$ of the number of prey ingested. Nematoscelis euphausiids were important in the diet throughout the sampling period as well, and January 1986 excepted, accounted for over $10 \%$ of the food items.

Diel periodicity in feeding was examined by comparing the total number of food items in guts for the time periods listed in 'Methods' (Fig. 8). For the 3 size groups of Gonostoma elongatum analysed, guts were fullest at night (21:00 to 5:00 h) with the largest average values being approximately twice those for daytime $(7: 00$ to $18: 00 \mathrm{~h})$. Student t-tests showed this difference to be significant $(p<0.05)$.

\section{DISCUSSION}

\section{Hydrographic setting}

The Loop Current is that portion of the Gulf Stream System connecting the Yucatan Current and the Florida Current in the eastern Gulf (Maul 1977). It generally

Table 4. Gonostoma elongatum. Comparison of percentages of each prey type consumed by the 110-130 mm size class with plankton composition at depths of occurrence of this size class

\begin{tabular}{|c|c|c|c|}
\hline Food type & $\begin{array}{c}\text { Diet of } G \text {. elongatum } \\
110-130 \mathrm{~mm} \\
\text { No. fish }=178 \\
\text { No. food items }=508\end{array}$ & $\begin{array}{l}150-200 \mathrm{~m} \\
\text { (night) }\end{array}$ & $\begin{array}{l}600-700 \mathrm{~m} \\
\text { (day) }\end{array}$ \\
\hline $\begin{array}{l}\text { Copepods } \\
1-6 \mathrm{~mm}\end{array}$ & 46 & 75 & 95 \\
\hline $\begin{array}{l}\text { Pleuromamma spp. } \\
1-6 \mathrm{~mm}\end{array}$ & 27 & 6 & 1 \\
\hline $\begin{array}{l}\text { Conchoecid ostracods } \\
0.5-3 \mathrm{~mm}\end{array}$ & 33 & 6 & 1 \\
\hline $\begin{array}{l}\text { Non-crustacean invertebrates } \\
5-20 \mathrm{~mm}\end{array}$ & 3 & 65 & 21 \\
\hline
\end{tabular}


Table 5. Gonostoma elongatum. Intercruise comparison of major diet components of the $110-130 \mathrm{~mm}$ size class. Values in body of table are percentages of food items in all guts of that cruise

\begin{tabular}{|c|c|c|c|c|c|c|c|}
\hline Diet component & $\begin{array}{l}\text { Date: } \\
\text { No. food items: } \\
\text { No. guts examined/ } \\
\text { no. guts with food: }\end{array}$ & $\begin{array}{c}\text { Jan } 1986 \\
50 \\
23 / 20\end{array}$ & $\begin{array}{c}\text { Mar } 1985 \\
27 \\
14 / 12\end{array}$ & $\begin{array}{l}\text { May } 1986 \\
\quad 86 \\
27 / 22\end{array}$ & $\begin{array}{c}\text { Jul } 1985 \\
114 \\
31 / 29\end{array}$ & $\begin{array}{c}\text { Sep } 1984 \\
148 \\
62 / 56\end{array}$ & $\begin{array}{l}\text { Nov } 1985 \\
116 \\
52 / 47\end{array}$ \\
\hline Pleuromamma spp. & & 26 & 15 & 30 & 31 & 21 & 22 \\
\hline Total copepods & & 48 & 30 & 43 & 52 & 43 & 41 \\
\hline Conchoecid ostracods & & 24 & 26 & 9 & 15 & 12 & 6 \\
\hline Stylocheiron spp. & & 10 & 4 & 7 & 4 & 10 & 9 \\
\hline Nematoscelis spp. & & 6 & 19 & 17 & 11 & 14 & 21 \\
\hline Total euphausiids & & 18 & 30 & 33 & 21 & 30 & 38 \\
\hline $\begin{array}{l}\text { Total of major compon } \\
\text { (copepods, ostracods \& } \\
\text { euphausids) }\end{array}$ & & 90 & 86 & 85 & 88 & 85 & 85 \\
\hline
\end{tabular}

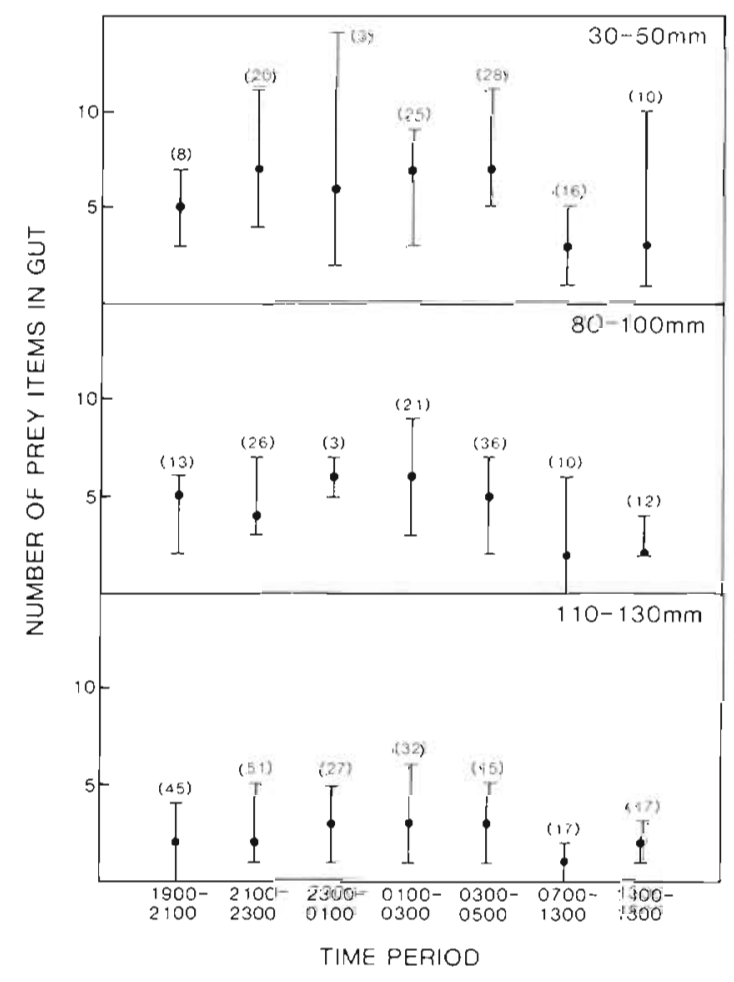

Fig. 8. Gonostoma elongatum. Diel feeding patterns in 3 size classes. Solid circle is median number of prey items in guts; vertical bar is range between 17 th and 83 rd percentiles, i.e. includes the central $2 / 3$ of the values; number in parentheses are numbers of guts examined

penetrates furthest into the Gulf during the summer though there is a variable annual cycle of growth and decay (Maul 1977). The eastern boundary of the warm and saline Loop water generally moves down the west coast of Florida mixing with the cooler, fresher resident Gulf water to form the transitional water that occupied the study area for all of the cruises except March 1985.
Primary productivity in the eastern Gulf of Mexico is low (El-Sayed 1972) with transition waters generally being slightly more productive (Bogdanov et al. 1968, Hopkins 1982). Our unpublished integrated (0 to $200 \mathrm{~m}$ ) seasonal chlorophyll a values averaged $29 \mathrm{mg}$ $\mathrm{m}^{-2}$ (range for $5 \mathrm{mo}: 12$ to $64 \mathrm{mg} \mathrm{m}^{-2}$ ). Low zooplankton standing stock from a previous study (Hopkins 1982) and our study (average: $1.8 \mathrm{~g} \mathrm{DW} \mathrm{m}^{-2}$, range for $8 \mathrm{mo}$ : 1.3 to $2.9 \mathrm{~g} \mathrm{DW} \mathrm{m}^{-2}$ ) also enabled us to characterize the study area as oligotrophic.

\section{Biology}

In the eastern Gulf of Mexico the entire population of Gonostoma elongatum vertically migrated about $400 \mathrm{~m}$ with larger fish living deeper. Other authors (Clarke 1974, Badcock \& Merrett 1976) have suggested that some adults do not regularly undergo diel migrations but also indicated a positive size-depth relationship. $G$. elongatum was found in greater depths in those studies (down to $1500 \mathrm{~m}$ in the northeast Atlantic) than in the Gulf but was never found shallower than $25 \mathrm{~m}$. Apparently G. elongatum, like many Gulf myctophids (Gartner et al. 1987), avoids the higher temperatures of the upper mixed layer in lower latitude ecosystems.

In the upper $1000 \mathrm{~m}$ of the Gulf of Mexico, the numerical abundance $\left(0.199\right.$ fish $\left.\mathrm{m}^{-2}\right)$ and standing crop $\left(75.6 \mathrm{mg} \mathrm{DM} \mathrm{m} \mathrm{m}^{-2}\right.$ ) of Gonostoma elongatum were higher than from many other Gulf mesopelagic fish. Hopkins \& Baird (1985a) reported sternoptychids ranging from 0.021 to 0.053 fish $\mathrm{m}^{-2}$ In another paper (Hopkins \& Baird 1985b), one species of abundant lanternfish, Lampanyctus alatus, averaged 0.14 fish $\mathrm{m}^{-2}$ (10 $\mathrm{mg} \mathrm{DW} \mathrm{m}^{-2}$ ). While some of the 7 most abundant myctophids in the Gulf (Gartner et al. 1987) may equal or exceed the numbers of $G$. elongatum, its contribution to overall biomass (0 to $1000 \mathrm{~m}$ ) was nearly equal 
to all 7 species combined (based on data from Hopkins \& Lancraft 1984). Cyclothone species often occur in numbers many times that of other midwater fish (1 to 2 fish $\mathrm{m}^{-2}$ ) but because of their dimunitive size and high water content (D. G. Stickney \& J. J. Torres unpubl.) they even contribute less than $G$. elongatum to overall dry weight biomass (Hopkins \& Lancraft 1984). Considering its size and abundance, G. elongatum is the most important stomiiform species and potentially the most important midwater fish in the Gulf of Mexico.

Subtropical waters are typified by small seasonal changes (Blackburn 1981. Hayward 1986) and the study area was no exception (Bogdanov et al. 1968, this study). Small changes in Gonostoma elongatum abundance, with maxima slightly more than twice minima, were observed. Other investigators (Maynard et al. 1975, Blackburn 1981), observing approximately 2 -fold temporal variations in standing stock of some tropical-subtropical micronektonic groups, could not find any predictable seasonal cycle. In the central North Pacific, Hayward (1986) found a 2- to 3-fold variability in primary and secondary production that he attributed to meso-scale patchiness which, in turn, exceeded seasonal variation. If seasonal changes actually occur in the Gulf, their amplitudes are probably small enough to be masked by meso-scale patchiness generated by the unpredictable and ephemeral nature of the Loop Current (Leipper 1970, Maul 1977).

Reproductively mature fish and numerous juveniles were present during all periods indicating year-round breeding. Continual spawning has also been suggested for tropical myctophids (Oven 1985, Lisovenko \& Prut'ko 1986). However, because the largest fish were always ripe females, and since no large females were observed with only small eggs or spent ovaries, and because ripe female abundance dropped abruptly after the median age at spawning, it is suggested that female Gonostoma elongatum spawn without regard for season and only once a lifetime.

Several medium-sized tropical-subtropical myctophids are also thought to die after spawning (Gjosaeter \& Kawaguchi 1980). Semelparity also has been suggested for sternoptychids Maurolicus muelleri (Clarke 1982, Kawaguchi \& Mauchline 1987) and Argyropelecus hemigymnus (Kawaguchi \& Mauchline 1987) as well as several bathypelagic fish (Childress et al. 1980). However, Fisher (1983) and we in our study encountered fish with ovaries containing biomodal egg sizes, so a second spawning is possible. Badcock \& Merrett (1976) identified spent ovaries in eastern North Atlantic Gonostoma elongatum and suggested a second spawning for individuals larger than $238 \mathrm{~mm}$ SL. However, since this size exceeds our maximum size it is doubtful that a second spawning commonly occurs in the Gulf.
The microstructure of otoliths and their use in estimating age encompasses a vast body of literature, reviewed by Campana \& Neilson (1985). These authors, concerned as to the exact periodicity of the formation of increments, suggested a unifying hypothesis consistent with the numerous and often contradictory age and growth studies they reviewed. An endogenously controlled circadian rhythm (24h), entrained by photoperiod and potentially modified by environmental factors was postulated as the controlling factor of increment formation (Campana \& Neilson 1985). Pannella (1980) found that fish exhibiting pronounced diel activities (e.g. vertical migration and distinct feeding periods) tend to have more distinct daily increments than non-migratory and non-cyclical feeding fish. Since Gonostoma elongatum is a strong daily migrator and displays a daily feeding chronology it is probable that the increments counted are daily in nature.

There was a close correspondence between the number of increments counted in recently metamorphosed individuals (60 at $23 \mathrm{~mm}$ SL) and an abrupt change in otolith growth (57 increments) that can be interpreted as a metamorphic check (Gjosaeter 1987). Our counts suggest a 2 mo interval before metamorphosis in Gonostoma elongatum, a value which agrees well with that observed in other mesopelagic species (Methot 1981, Miya \& Nemoto 1986, Gjosaeter 1987), and serves as an indicator of the accuracy of the technique. Because of these observations we feel that primary rings are formed daily (i.e. 60 rings in $2 \mathrm{mo}$ ) in $G$. elongatum otoliths

Our growth rate for Gonostoma elongatum is unique in that it is the first stomiiform growth rate estimated by using daily growth increments. $G$. elongatum was found to live less than 2 yr growing linearly at a rate of $0.34 \mathrm{~mm} \mathrm{~d}^{-1}$ to a maximum size of $225 \mathrm{~mm}$ SL. Linear growth has been reported in other stomiiforms (Childress et al. 1980, Miya \& Nemoto 1987) as well as deepliving myctophids (Childress et al. 1980). Other authors (J. Gjosaeter 1984, J. Gjosaeter et al. 1984, H. Gjosaeter 1987), using daily increment counts, estimated tropical myctophid growth rates ranging between 0.16 and $0.36 \mathrm{~mm} \mathrm{~d}^{-1}$ with lifespans of less than 1 yr. Clarke (1974), using length-frequency data, estimated a growth rate of 70 to $100 \mathrm{~mm} \mathrm{yr}^{-1}\left(0.19\right.$ to $\left.0.27 \mathrm{~mm} \mathrm{~d}^{-1}\right)$ for Chauliodus sloani, another large subtropical stomiiform (maximum size $=250 \mathrm{~mm}$ SL). Annual lifespans for small tropical-subtropical myctophids have been suggested by Clarke (1973) and Karnella \& Gibbs (1977) while larger myctophids are believed to require more than a year to reach maximum size (Clarke 1973), which is similar to $G$. elongatum.

Diet analysis reveals: (1) Gonostoma elongatum is predominantly a predator on crustaceans, (2) diet shifts 
to larger prey with growth, (3) both positive and negative food selection occurs, and (4) most feeding occurs in the epipelagic zone at night. The present results on diet composition confirm our earlier findings on $G$. elongatum (Hopkins \& Baird 1975, 1977) and are in general agreement with those of Clarke (1978) and Gorelova (1981). Also, our data concur with Gorelova's (1981) in demonstrating a change in diet with increasing fish size. Our results show a proportional shift from copepods and ostracods in the diet of fishes $<50 \mathrm{~mm}$ SL, to euphausiids in older fish. Gorelova's (1981) results show a sequence wherein copepods and amphipods are dominant prey of juveniles $<50 \mathrm{~mm} \mathrm{SL}$, euphausiids at intermediate fish sizes and fish in the diets of the largest individuals (>120 mm SL). Fish were infrequently encountered in our analyses in that only 24 occurred among a total of 1967 food items. However, only $15 \mathrm{G}$. elongatum $>130 \mathrm{~mm}$ SL were available to us, this being the size class most likely to prey on other fishes. Our data show strong positive prey selection by $G$. elongatum for ostracods and particularly for the copepod genus Pleuromamma and are in agreement with Gorelova's (1981) findings of an obvious strong negative selection for non-crustacean invertebrate prey. Also we found a cyclic feeding pattern as did Gorelova (1981), though Gorelova's results show stomachs were fullest at 19:00 to 23:00 h whereas we found maximum fullness later at night, at 23:00 to 5:00 h. Clarke (1978) was unable to discern diel periodicity in $G$. elongatum feeding off Hawaii, though this may have been a function of small sample size and the wide size range of his material.

As quantitative data were available for both Gonostoma elongatum (Fig. 4) and plankton (see 'Methods') we estimated predation impact of this abundant fish on one of its principal food items, Pleuromamma spp. These data come from the summer RV 'Columbus Iselin' cruises ('Methods'; Table 1). To do this we calculated the abundance (number $\mathrm{m}^{-2}$ ) of various size classes of $G$. elongatum and Pleuromamma in the upper $1000 \mathrm{~m}$. We then calculated the 'daily ration' of Pleuromamma for each size class of $G$. elongatum (Table 6). 'Daily ration' of Pleuromamma is here defined as the average number of these copepods in the guts of fishes taken between 23:00 and 5:00 h when guts were fullest. Pleuromamma was selected not only because it is a major component of the diet but also because it can be quantitatively accounted for throughout the digestive tract. The metasomal spot characteristic of this genus is easily recognized and is refractory to digestion as is much of the exoskeleton and diagnostic mandibles of Pleuromamma. Ours is probably a minimal estimate of daily ration because some fishes may have been captured before they had fed, some of the prey eaten earlier in the evening may have been egested, and some prey could have been eaten and egested at depth during the day. Regarding the latter, our data do indicate guts were least full during the day which suggests most feeding occurs at night. Further, 'daily ration' computed by this method and with the Elliot \& Persson (1978; see also Clarke 1978) gastric evacuation method gave comparable results for Lampanyctus alatus, a myctophid with a similar feeding cycle (Hopkins \& Baird 1985b) to G. elongatum.

Table 6 shows that Gonostoma elongatum removes 0.025 Pleuromamma $\mathrm{m}^{-2} \mathrm{~d}^{-1}$ in the 1 to $6 \mathrm{~mm}$ size range. Predation impact is unequal over the size range of Pleuromamma in that greatest pressure falls on $>3 \mathrm{~mm}$ copepods, that is, on adult $P$. abdominalis and on copepodite Stage 5 and adult $P$. xiphias. For example, it would require $10^{5} \mathrm{~d}$ for $G$. elongatum to remove the existing standing stock of 1 to $2 \mathrm{~mm}$ Pleuromamma (mostly adult $P$. gracilis and $P$. piseki) assuming no replacement, but only $208 \mathrm{~d}$ for removal of $>4 \mathrm{~mm}$ Pleuromamma (adult $P$, xiphias). If it is assumed that most feeding occurs after both predator and prey have reached their night-time depths (the fact that stomachs are fullest after 23:00 h suggests this is the case) then the data in Table 7 predict that vertical distribution of predation impact is uneven. Heaviest pressure occurs in the 150 to $200 \mathrm{~m}$ zone, especially on $>3 \mathrm{~mm}$ Pleuromamma.

Since the probable daily removal rate by post-larval Gonostoma elongatum is less than $0.1 \%$, this species alone has relatively little impact on Pleuromamma. However, the eastern Gulf, as characteristic of low latitude oceanic ecosystems, has high micronekton diversity and weak species dominance (e.g. Hopkins \&

Table 6. Gonostoma elongatum. Removal rate of Pleuromamma spp. in upper $1000 \mathrm{~m}$

\begin{tabular}{|c|c|c|c|c|c|}
\hline & \multicolumn{5}{|c|}{ Pleuromamma length (mm) } \\
\hline & $1-2$ & $2-3$ & $3-4$ & $>4$ & Total \\
\hline No. $\mathrm{m}^{-2}$ & 730 & 202 & 94 & 27 & 1053 \\
\hline No. eaten $\mathrm{m}^{-2}$ & 0.008 & 0.015 & 0.105 & 0.130 & 0.258 \\
\hline$\%$ eaten $d^{-1}$ & 0.001 & 0.007 & 0.112 & 0.481 & 0.025 \\
\hline $\begin{array}{l}\text { Days required to consume } \\
\text { standing stock }\end{array}$ & $10^{5}$ & $1.4 \times 10^{4}$ & 893 & 208 & \\
\hline
\end{tabular}


Table 7. Gonostoma elongatum. Estimated removal rate by depth of Pleuromamma spp. in upper $250 \mathrm{~m}$ at night. Numbers are no. eaten $100 \mathrm{~m}^{-2}$ in each depth zone

\begin{tabular}{|c|c|c|c|c|c|}
\hline \multirow{2}{*}{$\begin{array}{l}\text { Depth } \\
\text { (m) }\end{array}$} & \multicolumn{5}{|c|}{ Pleuromamma length $(\mathrm{mm})$} \\
\hline & $1-2$ & $2-3$ & $3-4$ & $>4$ & Total \\
\hline $25-50$ & 0.39 & 0.29 & 0.45 & 0.10 & 1.23 \\
\hline $50-100$ & 0.09 & 0.08 & 0.20 & 0.07 & 0.44 \\
\hline $100-150$ & 0.21 & 0.43 & 2.37 & 1.54 & 4.55 \\
\hline $150-200$ & - & 0.61 & 6.00 & 7.49 & 14.10 \\
\hline $200-250$ & 0.10 & 0.12 & 1.40 & 3.78 & 5.46 \\
\hline
\end{tabular}

Lancraft 1984). Our data and those of others indicate that Pleuromamma is an important prey item for a number of relatively abundant species of fishes (Merrett \& Roe 1974, Hopkins \& Baird 1977, 1981, 1985b, Clarke 1980, Gorelova 1981, Kinzer \& Schulz 1985), shrimps (Foxton \& Roe 1974, Heffernan \& Hopkins 1981, Flock \& Hopkins 1987), and even squids (e.g. Pterygioteuthis gemmata, P. giardi and Histioteuthis margaritifera; K. Passarella pers. comm.). The relatively small predation impact calculated for $G$. elongatum, then, may be typical for other abundant micronekton species feeding on this genus.

Acknowledgements. The senior author thanks the Florida Department of Natural Resources for the use of their microscope-camera system and, especially, K. Peters for his invaluable aid in otolith structure interpretation. Many thanks go to D. Bombard for typing this paper in all its many versions. Thanks are also due D. Kirwan for helping in developing the mathematical expressions enabling us to calculate vertical zonation of predation rates. The research was supported by NSF contracts DES 75-03845, OCE 75-03845 and OCE 8410787.

\section{LITERATURE CITED}

Backus, R. H., Craddock, J. E. (1982). Mesopelagic fishes in Gulf Stream cold-core rings. J. mar. Res. 40 (Suppl.): 1-20

Backus, R. H., Craddock, J. E., Haedrich, R. L., Shores, D. L. (1970). The distribution of mesopelagic fishes in the Equatorial and Western North Atlantic Ocean. J. mar. Res. 28: 179-201

Badcock, J. (1984). Gonostomatidae. In: Whitehead, P. J. P., Bauchot, M.-L., Hureau, J.-C., Neisen, J., Tortonese, E. (eds.) Fishes of the North-eastern Atlantic and the Mediterranean. UNESCO, Paris, p. 284-301

Badcock, J., Merrett, N. R. (1976). Midwater fishes in the eastern North Atlantic. I. Vertical distribution and associated biology in $30^{\circ} \mathrm{N}, 23^{\circ} \mathrm{W}$, with developmental notes on certain myctophids. Prog. Oceanogr. 7: 3-58

Bennett, J. L. (1986). Vertical distribution, abundance and feeding of the copepod genus Pleuromamma in the eastern Gulf of Mexico. Masters's thesis, University of South Florida

Blackburn, M. (1981). Low latitude gyral regions. In: Longhurst, A. R. (ed.) Analysis of marine ecosystems. Academic Press, London, p. 3-29

Bogdanov, D. V., Sokolov, V. A., Kromov, N. S. (1968). Regions of high biological and commercial productivity in the Gulf of Mexico and Caribbean Sea. Oceanology 8: 371-381

Campana, S. E., Neilson, J.D. (1985). Microstructure of fish otoliths. Can. J. Fish. Aquat. Sci, 42: 1014-1032

Childress, J. J., Taylor, S. M., Cailliet, G. M., Price, M. H. (1980). Patterns of growth, energy utilization and reproduction in some meso- and bathypelagic fishes off Southern California. Mar. Biol. 61: 27-40

Clarke, T. A. (1973). Some aspects of the ecology of lanternfishes (Myctophidae) in the Pacific Ocean near Hawail. Fish. Bull. U. S. 71: 401-434

Clarke, T. A. (1974). Some aspects of the ecology of stomiatoid fishes in the Pacific Ocean near Hawaii. Fish. Bull. U. S. 72: $337-351$

Clarke, T A. (1978). Diel feeding patterns of 16 species of mesopelagic fishes from Hawaiian waters. Fish. Bull. U. S. 76: 495-513

Clarke, T A. (1980). Diets of fourteen species of vertically migrating mesopelagic fishes in Hawaiian waters. Fish. Bull. U. S. 78: 619-640

Clarke, T. A. (1982). Distribution, growth and reproduction of the lightfish Maurolicus mueller (Stemoptychidae) off South-East Australia. CSIRO Marine Laboratories Report No. 145 p. $1-10$

Davies, I. E., Barham, E. G. (1969). The Tucker openingclosing micronekton net and its performance in a study of the deep scattering layer. Mar. Biol. 2: 127-131

Elliott, J. M., Persson, L. (1978). The estimation of daily rates of food consumption for fish. J. Anim. Ecol. 47: 977-980

El-Sayed, S. Z. (1972). Primary production and standing crop of phytoplankton. In: Bushnell, V. C. (ed.) Chemistry, primary productivity, and benthic algae of the Gulf of Mexico. Serial Atlas, Folio 22. American Geophysical Society, New York

Fisher, R. A. (1983). Protandric sex reversal in Gonostoma elongatum (Pisces; Gonostomatidae) from the eastern Gulf of Mexico. Copeia 1983: 554-557

Flock, M. E., Hopkins, T. L. (1987). The vertical distribution and feeding ecology of sergestid shrimps in the eastern Gulf of Mexico. ABSTRACT 31G-01 EOS 68: 1731

Foxton, P., Roe, H. S. J. (1974). Observations on the nocturnal feeding of some mesopelagic decapod crustacean. Mar. Biol. 28: $37-49$

Gartner, J. V. Jr, Hopkins, T. L., Baird, R. C., Milliken, D. M. (1987). The lanternfishes (Pisces: Myctophidae) of the eastern Gulf of Mexico. Fish. Bull. U. S. 85: 81-98

Gjosaeter, H. (1987). Primary growth increments in otoliths of six tropical myctophid species. Biol. Oceanogr. 4: 359-382

Gjosaeter, J. (1984). Mesopelagic fish: a large potential resource in the Arabian Sea. Deep Sea Res. 31: 1019-1035

Gjosaeter, J., Dayaratne, P., Bergstad, O. A., Gjosaeter, H., Sousa, M. I., Beck, M. I. (1984). Ageing tropical fish by 
growth rings in the otoliths. FAO Fish. Circ. No. 776, p. $1-54$

Gjosaeter, J., Kawaguchi, K. (1980). A review of the world resources of mesopelagic fish. FAO Fish. Tech. Paper No. 193, p. $1-15$

Gorelova, T. A. (1981). Notes on feeding and gonad condition in three species of the genus Gonostoma (Gonostomatidae). J. Ichthyol. 25: 82-92

Grey, M. (1964). Family Gonostomatidae. In: Olsen, Y. H. (ed.) Fishes of the western North Atlantic. Mem. Sears Fdn mar. Res. 1: 78-240

Hayward, T. L. (1986). Variability in production and the role of disturbance in two pelagic ecosystems. In: Pierrot-Bults, A. C. (ed.) Pelagic biogeography. UNESCO Tech. Papers Mar. Sci. 49: 133-140

Heffernan, J. J., Hopkins, T L. (1981). Vertical distribution and feeding of the shrimp genera Gennadas and Bentheogennema (Decapoda: Penaeidea) in the eastern Gulf of Mexico. J. Crust. Biol. 1: 461-473

Hopkins, T. L. (1982). The vertical distribution of zooplankton in the eastern Gulf of Mexico. Deep Sea Res. 29: 1069-1083

Hopkins, T L. (1987). The midwater food web in McMurdo Sound, Ross Sea, Antarctica. Mar. Biol. 96: 93-106

Hopkins, T. L., Baird, R. C. (1975). Net feeding in mesopelagic fishes. Fish. Bull. U. S. 73: 908-914

Hopkins, T. L., Baird, R. C. (1977). Aspects of the feeding ecology of oceanic midwater fishes. In: Andersen, N., Zahuranec, B. J. (eds.) Proc. Int. Symp. Prediction of sound scattering in the ocean. Plenum Press, New York, p. $325-360$

Hopkins, T. L., Baird, R. C. (1985a). Feeding ecology of four hatchetfishes (Sternoptychidae) in the eastern Gulf of Mexico. Bull. mar. Sci. 36: 160-277

Hopkins, T. L., Baird, R. C. (1985b). Aspects of the trophic ecology of the mesopelagic fish Lampanyctus alatus (Family Myctophidae) in the eastern Gulf of Mexico. Biol. Oceanogr 3: 285-313

Hopkins, T. L., Lancraft, T. M. (1984). The composition and standing crop of mesopelagic micronekton at $27^{\circ} \mathrm{N} 86^{\circ} \mathrm{W}$ in the eastern Gulf of Mexico. Contr. mar. Sci. 27: 143-158

Karnella, C., Gibbs, R. H., Jr (1977). The lanternfish Lobianchia dolfleini: an example of the importance of life-history information in prediction of oceanic sound scattering. In: Andersen, N. R., Zahuranec, B. J. (eds.) Oceanic sound scattering prediction. Plenum Press, New York, p. $361-379$
Kawaguchi, K., Mauchline, J. (1987). Biology of sternoptychid fishes in the Rockall Trough, northeastern Atlantic Ocean. Biol. Oceanogr. 4: 99-120

Kinzer, J,, Schulz, K. (1985). Vertical distribution and feeding patterns of midwater fish in the central equatorial Atlantic. Mar. Biol. 85: 313-322

Leipper, D. F. (1970). A sequence of current patterns in the Gulf of Mexico. J geophys. Res. 75: 637-657

Lisovenko, L. A., Prut'ko, V G. (1986). Reproductive biology of Diaphus suborbitalis (Myctophidae) in the equatorial part of the Indian Ocean. I. Nature of oogenesis and type of spawning. J. Ichthyol. 26: 47-58

Loeb, V. J. (1979). Larval fishes in the zooplankton community of the North Pacific Central Gyre. Mar. Biol. 53: 173-191

Maul, G. A. (1977). The annual cycle of the Gulf Loop Current. Part I: Observations during a one-year time series. J. mar. Res. 35: 23-47

Maynard, S. D., Riggs, F. D., Walters, J. F. (1975). Mesopelagic micronekton in Hawaiian waters: faunal composition, standing stock, and diel vertical migration. Fish. Bull. U.S. 73: 726-736

Merrett, N. R., Roe, H. S. J. (1974). Patterns and selectivity in the feeding of certain mesopelagic fishes. Mar. Biol. 28: $115-126$

Methot, R. D., Jr (1981). Spatial covariation of daily growth rates of larval northern anchovy, Engraulis mordax, and northern lampfish, Stenobrachius leucopsarus. Rapp. P.-v. Réun. Cons. int. Explor. Mer 178: 424-431

Miya, M., Nemoto, T (1986). Life history and vertical distribution of the mesopelagic fish Cyclothone alba (Family Gonostomatidae) in Sagami Bay, Central Japan. Deep Sea Res. 33: 1053-1068

Miya, M. Nemoto, T. (1987). Some aspects of the biology of the micronektonic fish Cyclothone pallida and C. acclinidens (Pisces: Gonostomatidae) in Sagami Bay, Central Japan. J. oceanogr. Soc. Jap. 42: 473-480

Mukhacheva, V. A. (1972). Material on taxonomy, distribution and biology of the species of Gonostoma (Pisces, Gonostomatidae). Tr. In-ta. Okeanol. Akademiia Nauk, SSSR 93: 205-249

Oven, L. S. (1985). Comparative analysis of reproductive biology of some lanternfishes (Myctophidae) from the tropical zone of the Atlantic Ocean. J. Ichthyol. 25: 50-60

Pannella, G. (1980). Growth patterns in fish sagittae. In Rhoads, D. C., Lutz, R. A. (eds.) Skeletal growth of aquatic organisms. Biological records of environmental change. Plenum Press, New York, p. 519-624 